\title{
Additivity of digestible energy and nutrient concentrations in hatchery byproducts fed to nursery pigs
}

\author{
Jung Yeol Sung ${ }^{1}$, Sang Yun $\mathrm{Ji}^{2}$, and Beob Gyun Kim ${ }^{1}$ *
}

* Corresponding Author: Beob Gyun Kim Tel: +82-2-2049-6255, Fax: +82-2-455-1044,

E-mail: bgkim@konkuk.ac.kr

1 Department of Animal Science and Technology, Konkuk University, Seoul 05029, Korea

${ }^{2}$ Animal Nutritional Physiology Team, National Institute of Animal Science, Rural Development Administration, Wanju 55363, Korea

ORCID

Jung Yeol Sung

https://orcid.org/0000-0001-9214-2724

Sang Yun Ji

https://orcid.org/0000-0001-7235-3655

Beob Gyun Kim

https://orcid.org/0000-0003-2097-717X

Submitted Mar 13, 2021; Revised Apr 28, 2021; Accepted Jun 19, 2021
Objective: The objective was to test additivity of digestible energy and nutrient concentrations in the hatchery byproduct mixture fed to nursery pigs.

Methods: In the previous studies, energy, phosphorus, calcium, and amino acid digestibility of infertile eggs, unhatched eggs, culled chicks, and a mixture of 3 hatchery byproduct ingredients was determined in nursery pigs (initial body weight $=9.4$ to $14.2 \mathrm{~kg}$ ). An additivity test was conducted using these determined values.

Results: No difference was observed between determined and predicted metabolizable energy values in the mixture (3,998 and 3,990 kcal/ $/ \mathrm{kg}$ as-is basis, respectively). Measured standardized total tract digestible phosphorus in the mixture was less than the predicted value ( $4.5 \mathrm{vs} 5.3 \mathrm{~g} / \mathrm{kg}$ as-is basis, respectively; $\mathrm{p}<0.05$ ). Measured standardized total tract digestible calcium in the mixture was greater compared with the predicted value (40.0 vs $31.7 \mathrm{~g} / \mathrm{kg}$ as-is basis, respectively; $\mathrm{p}<0.05$ ). Measured standardized ileal digestible tryptophan in the mixture was greater than the predicted value ( $3.7 \mathrm{vs} 3.1 \mathrm{~g} / \mathrm{kg}$ as-is basis, respectively; $\mathrm{p}<0.05)$ whereas other amino acid values were additive.

Conclusion: Energy and most of amino acid concentrations in hatchery byproducts are additive in the mixture fed to nursery pigs.

Keywords: Additivity; Hatchery Byproduct; Nutrient Utilization; Swine

\section{INTRODUCTION}

Additivity is the fundamental assumption when formulating diets using multiple ingredients. If a digestible energy (DE) value or a nutrient concentration in a mixed diet is equal to the proportional sum of $\mathrm{DE}$ values or nutrients from each ingredient, $\mathrm{DE}$ or nutrient concentration in the diet is regarded additive [1]. In layers hatchery facilities, infertile eggs, unhatched eggs, and culled chicks are regularly disposed of because only female chicks are economically valuable. These wastes from hatchery facilities are known as hatchery byproducts [2] and are regarded as alternative protein sources in nursery pig diets. A hatchery byproduct mixture could replace animal protein sources without compromising growth performance of nursery pigs [3]. For these reasons, the use of hatchery byproducts in swine diets would be both economically and environmentally beneficial. Generally, hatchery byproducts are pooled and then discarded together, but the ratio of each byproduct is not always constant.

An accurate nutritional evaluation of a feed ingredient is necessary for precise feed formulations [4,5]. To evaluate nutritional values of feed ingredients precisely, in vivo experiments with animals are required. However, it is nearly impossible to conduct in vivo experiments to determine nutritional value of hatchery byproduct mixtures whenever the ratio in the mixture changes. If the ratio of each component in the pooled hatchery byproduct mixture in layer hatchery facilities is known or estimated and if the energy 
and nutrient values are additive, available energy and nutrient concentrations in the mixture would be calculated as the proportional sum of energy and nutrients from each ingredient resulting in a precise feed formulation $[1,6]$. Therefore, the objective of the present study was to test the additivity of digestible energy, phosphorus $(\mathrm{P})$, calcium $(\mathrm{Ca})$, and amino acid (AA) concentrations in a hatchery byproduct mixture fed to nursery pigs based on previous metabolism studies $[4,7]$.

\section{MATERIALS AND METHODS}

All protocols used in the animal studies were approved by the Animal Care and Use Committee of Konkuk University (approval number: KU17049, KU18072, and KU18145). Four digestibility experiments were conducted in environmentally controlled rooms at Konkuk University.

\section{Data collection}

Digestible energy, metabolizable energy (ME), apparent total tract digestible (ATTD) P, standardized total tract digestible
(STTD) P, ATTD Ca, STTD Ca, apparent ileal digestible (AID) AA, and standardized ileal digestible (SID) AA in infertile eggs, unhatched eggs, culled chicks, and a mixture of 3 ingredients consisted of $200 \mathrm{~g} / \mathrm{kg}$ infertile eggs, $200 \mathrm{~g} / \mathrm{kg}$ unhatched eggs, and $600 \mathrm{~g} / \mathrm{kg}$ culled chicks (Table 1) fed to nursery pigs (initial body weight $=9.4$ to $14.2 \mathrm{~kg}$ ) were determined in our previous experiments [4,7]. The experimental diets for $\mathrm{DE}$ and $\mathrm{ME}$ measurement had constant corn to whey powder ratio to enable the calculation of $\mathrm{DE}$ and $\mathrm{ME}$ in the test ingredients using difference procedure (Table 2). The diets for $\mathrm{P}, \mathrm{Ca}$, and AA digestibility determination were formulated to contain a test ingredient as the sole source of $\mathrm{P}, \mathrm{Ca}$, or $\mathrm{AA}$ (Tables 3, 4, and 5), and thus, $\mathrm{P}, \mathrm{Ca}$, and AA digestibility values in an experimental diet represented the digestibility values in the ingredient. For energy, $\mathrm{P}$, and $\mathrm{Ca}$ studies, the marker-to-marker method was used to collect feces totally, whereas the index method was used in AA study. Antibiotics were not included in the experimental diets.

Calculations and statistical analyses

Digestible energy in infertile eggs, unhatched eggs, and culled

Table 1. Analyzed composition of hatchery byproducts, as-is basis ${ }^{1)}$

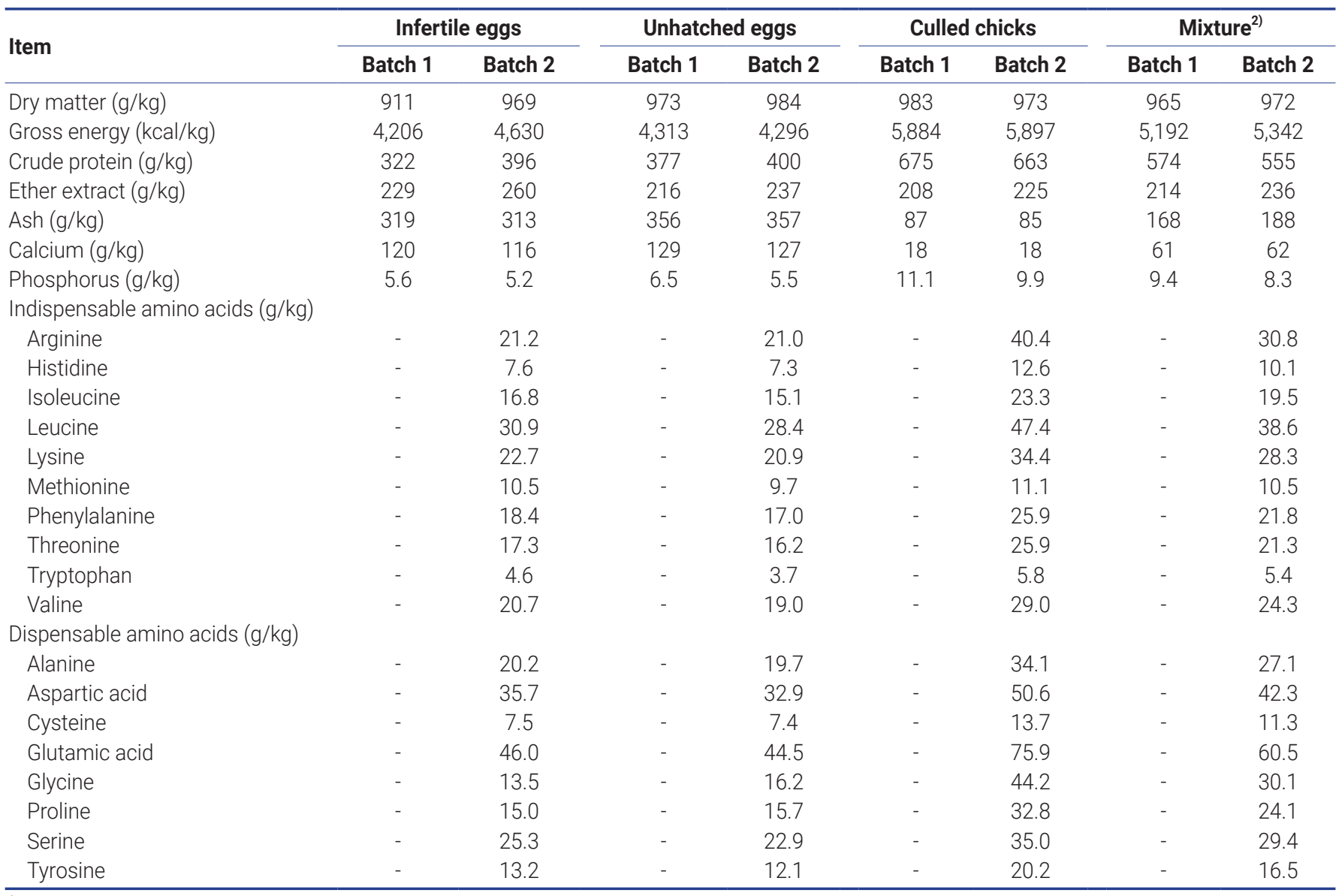

1) Analyzed composition of batches 1 and 2 were adapted from Sung et al [4,7], respectively. The batch 1 was used for the determination of energy and phosphorus digestibility. The batch 2 was used for calcium and amino acid digestibility experiments.

2) The mixture contained $200 \mathrm{~g} / \mathrm{kg}$ dried infertile eggs, $200 \mathrm{~g} / \mathrm{kg}$ dried unhatched eggs, and $600 \mathrm{~g} / \mathrm{kg}$ dried culled chicks. 
Table 2. Ingredient and chemical compositions of the experimental diets used in energy digestibility experiment, as-fed basis ${ }^{1)}$

\begin{tabular}{|c|c|c|c|c|c|}
\hline \multirow{2}{*}{ Item } & \multicolumn{5}{|c|}{ Diet } \\
\hline & Basal & Infertile egg & Unhatched egg & Culled chick & Mixture $^{2}$ \\
\hline \multicolumn{6}{|l|}{ Ingredient (g/kg) } \\
\hline Whey powder & 100.0 & 76.1 & 76.1 & 75.7 & 76.4 \\
\hline Infertile eggs & - & 250.0 & - & - & - \\
\hline Unhatched eggs & - & - & 250.0 & - & - \\
\hline Others ${ }^{3)}$ & 33.0 & 13.8 & 13.8 & 17.6 & 10.8 \\
\hline \multicolumn{6}{|l|}{ Analyzed composition } \\
\hline Dry matter (g/kg) & 904 & 909 & 921 & 920 & 919 \\
\hline Gross energy (kcal/kg) & 3,850 & 3,971 & 4,006 & 4,369 & 4,274 \\
\hline Crude protein (g/kg) & 95 & 157 & 164 & 237 & 207 \\
\hline
\end{tabular}

1) Adapted from Sung et al $[4,7]$.

2) The mixture contained $200 \mathrm{~g} / \mathrm{kg}$ dried infertile eggs, $200 \mathrm{~g} / \mathrm{kg}$ dried unhatched eggs, and $600 \mathrm{~g} / \mathrm{kg}$ dried culled chicks.

3) Others were limestone, monosodium phosphate, sodium chloride, vitamin premix, and mineral premix.

Table 3. Ingredient and chemical compositions of the experimental diets used in phosphorus digestibility experiment, as-fed basis ${ }^{1)}$

\begin{tabular}{|c|c|c|c|c|c|}
\hline \multirow{2}{*}{ Item } & \multicolumn{5}{|c|}{ Diet } \\
\hline & Infertile egg & Unhatched egg & Culled chick & Mixture ${ }^{2)}$ & P-free \\
\hline \multicolumn{6}{|l|}{ Ingredient (g/kg) } \\
\hline Infertile eggs & 250.0 & - & - & - & - \\
\hline Unhatched eggs & - & 250.0 & - & - & - \\
\hline Culled chicks & - & - & 250.0 & - & - \\
\hline Gelatin & 90.0 & 80.0 & - & 40.0 & 150.0 \\
\hline Others ${ }^{3)}$ & 7.5 & 7.5 & 14.4 & 7.5 & 129.8 \\
\hline \multicolumn{6}{|l|}{ Analyzed composition } \\
\hline Dry matter (g/kg) & 923 & 935 & 941 & 933 & 927 \\
\hline Gross energy (kcal/kg) & 3,984 & 3,943 & 4,241 & 4,127 & 3,998 \\
\hline
\end{tabular}

1) Adapted from Sung et al $[4,7]$.

${ }^{2)}$ The mixture contained $200 \mathrm{~g} / \mathrm{kg}$ dried infertile eggs, $200 \mathrm{~g} / \mathrm{kg}$ dried unhatched eggs, and $600 \mathrm{~g} / \mathrm{kg}$ dried culled chicks.

${ }^{3)}$ Others were cellulose, soybean oil, crystalline amino acids, limestone, potassium carbonate, magnesium oxide, sodium chloride, vitamin premix, and mineral premix.

chicks measured in the previous study [4] were used for calculating the predicted DE $(\mathrm{kcal} / \mathrm{kg})$ in the mixture according to the following equation modified from Kong and Adeola [8]:

$$
\begin{aligned}
& \text { Predicted } \mathrm{DE}_{\text {Mixture }} \\
& =\left(\mathrm{DE}_{\text {Infertile eggs }}+\mathrm{DE}_{\text {Unhatched eggs }}+3 \times \mathrm{DE}_{\text {Culled chicks }}\right) / 5
\end{aligned}
$$

where predicted $\mathrm{DE}_{\text {Mixture }}$ is predicted $\mathrm{DE}$ in the mixture and $\mathrm{DE}_{\text {Infertile eggs }}, \mathrm{DE}_{\text {Unhatched eggs, }}$, and $\mathrm{DE}_{\text {Culled chicks }}$ are measured $\mathrm{DE}$ values in infertile eggs, unhatched eggs, and culled chicks, respectively. Predicted values for $\mathrm{ME}(\mathrm{kcal} / \mathrm{kg})$ and digest- ible P, Ca, and AA ( $\mathrm{g} / \mathrm{kg})$ in the mixture were calculated as same as DE using the reported values [4,7].

For the comparison between measured and predicted values, a t-test was used and an alpha level of 0.05 was used to determine significance [9].

\section{RESULTS}

In the previous studies, 2 batches of hatchery byproducts were obtained and dried separately [4,7]. The first batch was used in energy and $\mathrm{P}$ digestibility experiments and the second batch was employed for $\mathrm{Ca}$ and AA digestibility experiments. 
Table 4. Ingredient and chemical compositions of the experimental diets used in calcium digestibility experiment, as-fed basis ${ }^{1)}$

\begin{tabular}{|c|c|c|c|c|c|}
\hline \multirow{2}{*}{ Item } & \multicolumn{5}{|c|}{ Diet } \\
\hline & Infertile egg & Unhatched egg & Culled chick & Mixture ${ }^{2)}$ & Ca-free \\
\hline \multicolumn{6}{|l|}{ Ingredient (g/kg) } \\
\hline Ground corn & 764.7 & 769.8 & 733.9 & 778.0 & 828.9 \\
\hline Potato protein concentrate & 115.0 & 110.0 & - & 50.0 & 150.0 \\
\hline Infertile eggs & 100.0 & - & - & - & - \\
\hline Unhatched eggs & - & 100.0 & - & - & - \\
\hline Culled chicks & - & - & 250.0 & - & - \\
\hline Mixture & - & - & - & 150.0 & - \\
\hline Others ${ }^{3)}$ & 20.3 & 20.2 & 16.1 & 22.0 & 21.1 \\
\hline \multicolumn{6}{|l|}{ Analyzed composition } \\
\hline Dry matter (g/kg) & 882 & 882 & 892 & 883 & 871 \\
\hline Gross energy (kcal/kg) & 4,019 & 4,000 & 4,327 & 4,068 & 4,027 \\
\hline Crude protein (g/kg) & 203 & 199 & 216 & 182 & 196 \\
\hline Calcium (g/kg) & 12.4 & 11.8 & 4.8 & 9.0 & 0.9 \\
\hline Phosphorus (g/kg) & 4.8 & 4.4 & 4.6 & 4.9 & 4.6 \\
\hline
\end{tabular}

1) Adapted from Sung et al $[4,7]$.

2) The mixture contained $200 \mathrm{~g} / \mathrm{kg}$ dried infertile eggs, $200 \mathrm{~g} / \mathrm{kg}$ dried unhatched eggs, and $600 \mathrm{~g} / \mathrm{kg}$ dried culled chicks.

3) Others were monosodium phosphate, sodium chloride, vitamin premix, and mineral premix.

Table 5. Ingredient and chemical compositions of the experimental diets used in amino acid digestibility experiment, as-fed basis ${ }^{1)}$

\begin{tabular}{|c|c|c|c|c|c|}
\hline \multirow{2}{*}{ Item } & \multicolumn{5}{|c|}{ Diet } \\
\hline & Infertile egg & Unhatched egg & Culled chick & Mixture $^{2)}$ & $\mathrm{N}$-free \\
\hline \multicolumn{6}{|l|}{ Ingredient (g/kg) } \\
\hline Cornstarch & 479.3 & 480.1 & 479.9 & 482.5 & 680.0 \\
\hline Sucrose & 200.0 & 200.0 & 200.0 & 200.0 & 200.0 \\
\hline Infertile eggs & 300.0 & - & - & - & - \\
\hline Unhatched eggs & - & 300.0 & - & - & - \\
\hline Culled chicks & - & - & 300.0 & - & - \\
\hline Mixture & - & - & - & 300.0 & - \\
\hline Others ${ }^{3)}$ & 20.7 & 19.9 & 20.1 & 17.5 & 120.0 \\
\hline \multicolumn{6}{|l|}{ Analyzed composition } \\
\hline Dry matter (g/kg) & 936 & 940 & 936 & 936 & 925 \\
\hline Gross energy (kcal/kg) & 3,920 & 3,824 & 4,302 & 4,111 & 3,681 \\
\hline Crude protein (g/kg) & 119 & 119 & 200 & 160 & 3 \\
\hline Lysine (g/kg) & 7.0 & 6.8 & 10.1 & 8.3 & 0.1 \\
\hline Methionine (g/kg) & 3.2 & 2.9 & 3.2 & 3.2 & 0.1 \\
\hline Threonine (g/kg) & 5.4 & 5.3 & 7.7 & 6.4 & 0.1 \\
\hline Tryptophan (g/kg) & 1.5 & 1.5 & 1.4 & 1.5 & 0.0 \\
\hline
\end{tabular}

1) Adapted from Sung et al $[4,7]$.

2) The mixture contained $200 \mathrm{~g} / \mathrm{kg}$ dried infertile eggs, $200 \mathrm{~g} / \mathrm{kg}$ dried unhatched eggs, and $600 \mathrm{~g} / \mathrm{kg}$ dried culled chicks.

${ }^{3)}$ Others were soybean oil, cellulose, limestone, monosodium phosphate, potassium carbonate, magnesium oxide, sodium chloride, vitamin-mineral premix, and chromium oxide.

Analyzed compositions of each hatchery byproduct of 2 batches were comparable (Table 1). Energy concentration and nutrient utilization of each hatchery byproduct ingredient and the mixture are provided in Table 6.

No difference between measured and predicted values for $\mathrm{DE}$ and $\mathrm{ME}$ in the hatchery byproduct mixture of infertile eggs, unhatched eggs, and culled chicks was observed (Table 7). While measured ATTD P and STTD P in the mixture were less than predicted values $(p<0.05)$, measured ATTD
Ca and STTD Ca were greater than predicted values $(p<0.05)$. No difference was observed between measured and predicted AID and SID AA in the mixture except for tryptophan (Table 8).

\section{DISCUSSION}

Information on additivity of energy concentrations in animal protein sources for non-ruminants is very limited. In rumi- 
Table 6. Energy concentrations (as-is basis) and coefficient of nutrient digestibility of phosphorus (P), calcium (Ca), and amino acids (AA) in the hatchery byproducts ${ }^{1), 2}$

\begin{tabular}{|c|c|c|c|c|c|c|}
\hline Item $^{3)}$ & Infertile egg & Unhatched egg & Culled chick & Mixture $^{4)}$ & SEM & p-value \\
\hline Gross energy (kcal/kg) & 4,206 & 4,313 & 5,884 & 5,192 & - & - \\
\hline Digestible energy (kcal/kg) & $2,759^{d}$ & $3,735^{\mathrm{c}}$ & $4,840^{\mathrm{a}}$ & $4,224^{b}$ & 116 & $<0.001$ \\
\hline Metabolizable energy (kcal/kg) & $2,645^{c}$ & $3,625^{b}$ & $4,560^{\mathrm{a}}$ & $3,998^{b}$ & 123 & $<0.001$ \\
\hline CATTD of $P$ & $0.640^{\mathrm{a}}$ & $0.447^{b}$ & $0.438^{b}$ & $0.355^{b}$ & 0.042 & $<0.001$ \\
\hline CSTTD of $P$ & $0.817^{\mathrm{a}}$ & $0.616^{b}$ & $0.539^{b}$ & $0.474^{b}$ & 0.042 & $<0.001$ \\
\hline CATTD of $\mathrm{Ca}$ & $0.485^{b}$ & $0.383^{c}$ & $0.633^{\mathrm{a}}$ & $0.580^{\mathrm{a}}$ & 0.033 & $<0.001$ \\
\hline CSTTD of $\mathrm{Ca}$ & $0.533^{c}$ & $0.434^{d}$ & $0.756^{a}$ & $0.645^{b}$ & 0.033 & $<0.001$ \\
\hline CSID of crude protein & $0.750^{\mathrm{a}}$ & $0.713^{\mathrm{ab}}$ & $0.638^{b}$ & $0.682^{\mathrm{ab}}$ & 0.027 & 0.023 \\
\hline \multicolumn{7}{|l|}{ CSID of indispensable AA } \\
\hline Arginine & $0.815^{\mathrm{a}}$ & $0.791^{\mathrm{ab}}$ & $0.717^{b}$ & $0.738^{\mathrm{ab}}$ & 0.024 & 0.009 \\
\hline Histidine & $0.783^{\mathrm{a}}$ & $0.750^{\mathrm{ab}}$ & $0.683^{b}$ & $0.715^{\mathrm{ab}}$ & 0.027 & 0.027 \\
\hline Isoleucine & $0.820^{\mathrm{a}}$ & $0.779^{\mathrm{ab}}$ & $0.675^{\mathrm{c}}$ & $0.718^{\mathrm{bc}}$ & 0.028 & $<0.001$ \\
\hline Leucine & $0.842^{a}$ & $0.804^{\mathrm{ab}}$ & $0.706^{\mathrm{C}}$ & $0.749^{b c}$ & 0.027 & 0.001 \\
\hline Lysine & 0.810 & 0.793 & 0.777 & 0.795 & 0.026 & 0.740 \\
\hline Methionine & 0.836 & 0.810 & 0.809 & 0.834 & 0.024 & 0.606 \\
\hline Phenylalanine & $0.824^{\mathrm{a}}$ & $0.782^{\mathrm{ab}}$ & $0.670^{c}$ & $0.716^{\mathrm{bc}}$ & 0.027 & $<0.001$ \\
\hline Threonine & $0.788^{\mathrm{a}}$ & $0.750^{\mathrm{ab}}$ & $0.652^{b}$ & $0.700^{\mathrm{ab}}$ & 0.030 & 0.010 \\
\hline Tryptophan & $0.833^{\mathrm{a}}$ & $0.774^{\mathrm{ab}}$ & $0.513^{c}$ & $0.694^{b}$ & 0.030 & $<0.001$ \\
\hline Valine & $0.820^{\mathrm{a}}$ & $0.780^{\mathrm{ab}}$ & $0.662^{c}$ & $0.709^{\mathrm{bc}}$ & 0.027 & $<0.001$ \\
\hline \multicolumn{7}{|l|}{ CSID of dispensable AA } \\
\hline Alanine & 0.797 & 0.779 & 0.726 & 0.750 & 0.028 & 0.163 \\
\hline Aspartic acid & $0.719^{\mathrm{a}}$ & $0.665^{\mathrm{ab}}$ & $0.593^{b}$ & $0.626^{b}$ & 0.025 & 0.006 \\
\hline Cysteine & $0.723^{\mathrm{a}}$ & $0.623^{\mathrm{ab}}$ & $0.381^{c}$ & $0.525^{b}$ & 0.032 & $<0.001$ \\
\hline Glutamic acid & $0.810^{\mathrm{a}}$ & $0.782^{\mathrm{ab}}$ & $0.701^{\mathrm{b}}$ & $0.742^{\mathrm{ab}}$ & 0.026 & 0.017 \\
\hline Glycine & 0.645 & 0.656 & 0.586 & 0.598 & 0.047 & 0.465 \\
\hline Proline & 0.195 & 0.317 & 0.363 & 0.363 & 0.185 & 0.701 \\
\hline Serine & $0.741^{\mathrm{a}}$ & $0.714^{a}$ & $0.563^{b}$ & $0.620^{b}$ & 0.025 & $<0.001$ \\
\hline Tyrosine & $0.829^{a}$ & $0.779^{\mathrm{ab}}$ & $0.635^{\mathrm{c}}$ & $0.694^{\mathrm{bc}}$ & 0.031 & $<0.001$ \\
\hline
\end{tabular}

SEM, standard error of the means; CATTD, coefficient of apparent total tract digestibility; CSTTD, coefficient of standardized total tract digestibility; CSID, coefficient of standardized ileal digestibility.

1) Adapted from Sung et al $[4,7]$.

2) Each least squares mean represents 6 to 8 observations.

${ }^{3)}$ Basal endogenous losses ( $\mathrm{g} / \mathrm{kg}$ dry matter intake) were determined from pigs fed semi-purified diets: phosphorus, 0.36 ; calcium, 0.66; crude protein, 21.52; arginine, 0.69; histidine, 0.27 ; isoleucine, 0.44 ; leucine, 0.75 ; lysine, 0.73 ; methionine, 0.14 ; phenylalanine, 0.47 ; threonine, 0.92 ; tryptophan, 0.18 ; valine, 0.67; alanine, 0.86; aspartic acid, 1.17; cysteine, 0.30; glutamic acid, 1.58; glycine, 1.56; proline, 3.11; serine, 0.91; tyrosine, 0.40.

${ }^{4)}$ The mixture contained $200 \mathrm{~g} / \mathrm{kg}$ dried infertile eggs, $200 \mathrm{~g} / \mathrm{kg}$ dried unhatched eggs, and $600 \mathrm{~g} / \mathrm{kg}$ dried culled chicks.

${ }^{a-d}$ Least squares means within a row without a common superscript differ $(p<0.05)$.

nants, energy concentrations may not be additive if a mixed diet is composed of forages and readily available carbohydrates due to changes in $\mathrm{pH}$ value, volatile fatty acid production, and microbial activity in the rumen which significantly affect energy metabolism [10]. In contrast to ruminants, the DE and ME values in feed ingredients for pigs are known to be additive in the mixed diets containing feed ingredients including corn, soybean meal, camelina cake, and wheat bran $[11,12]$. The additivity assumption on energy concentrations in swine diets may be violated if the proportion of a high-fiber ingredient in a mixed diet is very high likely due to negative effects of dietary fiber on energy digestibility of other ingredients. If a high-fiber ingredient in a mixed diet impedes energy utilization of other ingredients in the mixed diets, an actual energy concentration in the mixed diet would be less than the value calculated assuming additivity. In the present work, energy concentrations were additive in the hatchery byproduct mixture as hatchery byproducts are animal protein sources containing very little fiber.

The hatchery byproduct mixture used by Sung et al $[4,7]$ contained infertile eggs, unhatched eggs, and culled chicks. The classification of each hatchery byproduct ingredient is based on the hatchery process. Infertile eggs are the eggs identified as infertile on day 8 post-fertilization. Fertile eggs are incubated until day 21 post-fertilization. Unhatched eggs are the eggs where embryonic development ceases or a chick does not break eggshells until day 21 post-fertilization. Culled chicks are weak chicks or male chicks that cannot lay eggs. 
Table 7. Measured and predicted values for energy, phosphorus $(P)$, and calcium $(\mathrm{Ca})$ concentrations in the hatchery byproduct mixture, as-is basis

\begin{tabular}{lcccc}
\hline Item & Measured & Predicted & $\begin{array}{c}\text { Standard } \\
\text { error }^{1)}\end{array}$ & p-value \\
\hline DE $(\mathrm{kcal} / \mathrm{kg})$ & 4,224 & 4,203 & 199 & 0.890 \\
ME $(\mathrm{kcal} / \mathrm{kg})$ & 3,998 & 3,990 & 219 & 0.959 \\
ATTD P $(\mathrm{g} / \mathrm{kg})$ & 3.3 & 4.2 & 0.2 & 0.003 \\
STTD P $(\mathrm{g} / \mathrm{kg})$ & 4.5 & 5.3 & 0.2 & 0.004 \\
ATTD Ca $(\mathrm{g} / \mathrm{kg})$ & 36.0 & 27.9 & 1.9 & 0.004 \\
STTD Ca $(\mathrm{g} / \mathrm{kg})$ & 40.0 & 31.7 & 1.9 & 0.004 \\
\hline
\end{tabular}

$\mathrm{DE}$, digestible energy; ME, metabolizable energy; ATTD, apparent total tract digestible; STTD, standardized total tract digestible.

1) Standard error of the difference between measured and predicted values.

The STTD P or Ca and SID AA have been reported to be more additive compared with ATTD and AID nutrients in the mixture [13-15]. The reason for the non-additivity of apparent digestible nutrients in the mixture is an underestimation of ingredient nutrient digestibility particularly when a nutrient concentration is low mainly due to basal endogenous losses of nutrients $[1,6]$. In contrast to the ATTD and AID nutrients, STTD and SID nutrients are independent of basal endogenous losses of nutrients because these values are calculated by correcting apparent digestible nutrients for basal endogenous losses [16-19]. For this reason, NRC [20] sug- gested that diet formulations and requirements should be expressed on STTD P and SID AA.

In the present work, predicted ATTD and STTD P in the mixture were greater than the measured values, indicating that digestible $\mathrm{P}$ concentrations in the hatchery byproducts are not additive in the mixture. The non-additivity of digestible $\mathrm{P}$ in the mixture may be partially due to different $\mathrm{Ca}$ to $\mathrm{P}$ ratios among the experimental diets. Phosphorus digestibility in pigs was reported to linearly decrease as the dietary Ca concentration increased from 7 to $23 \mathrm{~g} / \mathrm{kg}$ when dietary $\mathrm{P}$ concentration was below the requirement [21]. The lower $\mathrm{P}$ digestibility with high $\mathrm{Ca}$ to $\mathrm{P}$ ratio in diets is likely due to the Ca-P complex formed by increased dietary $\mathrm{Ca}$, which eventually impedes $\mathrm{P}$ from being absorbed. The contribution of $\mathrm{P}$ provided by culled chicks accounts for the largest proportion of total $\mathrm{P}$ (approximately $73 \%$ ) in the mixture and $\mathrm{Ca}$ to $\mathrm{P}$ ratio in the mixture diet is more than twice of that in culled chick diet (4.4 vs 2.0 ). The low P digestibility in the mixture diet appears to be mainly attributed to the large $\mathrm{Ca}$ to $\mathrm{P}$ ratio. The $\mathrm{P}$ digestibility measured in the culled chick diet perhaps was not reflected in the mixed diet. In other studies, however, standardized or true total tract P digestibility values in mixed diets containing various cereal grains and oilseed meals were additive $[13,22,23]$. The Ca to $P$ ratios in the experimental diets used in those studies ranged from 0.6 to 1.5 , indicating that a non-excessive $\mathrm{Ca}$ to $\mathrm{P}$ ratio

Table 8. Measured and predicted values for digestible crude protein and amino acid (AA) concentrations ( $\mathrm{g} / \mathrm{kg}$ ) in the hatchery byproduct mixture, as-is basis

\begin{tabular}{|c|c|c|c|c|c|c|c|c|}
\hline \multirow{2}{*}{ Item } & \multicolumn{4}{|c|}{ Apparent ileal digestible } & \multicolumn{4}{|c|}{ Standardized ileal digestible } \\
\hline & Measured & Predicted & $\mathbf{S E}^{1)}$ & $\mathrm{p}$-value & Measured & Predicted & SE & p-value \\
\hline \multicolumn{9}{|l|}{ Indispensable AA } \\
\hline Arginine & 20.5 & 21.9 & 0.7 & 0.113 & 22.8 & 24.2 & 0.7 & 0.125 \\
\hline Histidine & 6.3 & 6.6 & 0.3 & 0.557 & 7.2 & 7.4 & 0.3 & 0.621 \\
\hline Isoleucine & 12.5 & 13.2 & 0.6 & 0.583 & 14.0 & 14.6 & 0.6 & 0.634 \\
\hline Methionine & 8.3 & 8.3 & 0.3 & 0.565 & 8.8 & 8.7 & 0.3 & 0.603 \\
\hline Phenylalanine & 14.1 & 14.6 & 0.7 & 0.671 & 15.6 & 16.1 & 0.7 & 0.712 \\
\hline Threonine & 12.0 & 12.5 & 0.7 & 0.731 & 14.9 & 15.3 & 0.7 & 0.805 \\
\hline Tryptophan & 3.1 & 2.5 & 0.2 & 0.004 & 3.7 & 3.1 & 0.2 & 0.004 \\
\hline Valine & 15.0 & 15.8 & 0.7 & 0.487 & 17.2 & 17.9 & 0.7 & 0.558 \\
\hline Glutamic acid & 40.0 & 41.5 & 1.6 & 0.548 & 44.9 & 46.3 & 1.6 & 0.587 \\
\hline Glycine & 13.1 & 14.7 & 0.9 & 0.169 & 18.0 & 19.4 & 0.9 & 0.221 \\
\hline Proline & -0.5 & -0.3 & 4.0 & 0.930 & 8.7 & 8.7 & 4.0 & 0.967 \\
\hline Serine & 15.4 & 16.1 & 0.8 & 0.533 & 18.2 & 18.8 & 0.8 & 0.585 \\
\hline Tyrosine & 10.1 & 10.4 & 0.6 & 0.848 & 11.5 & 11.8 & 0.6 & 0.896 \\
\hline
\end{tabular}

SE, standard error.

1) Standard error of the difference between measured and predicted values. 
in diets is important for the additivity of digestible $\mathrm{P}$ in the mixture.

In contrast to P, predicted ATTD and STTD Ca were less than measured values. The reason for the non-additivity of digestible $\mathrm{Ca}$ in the mixture may be also attributed to different $\mathrm{Ca}$ to $\mathrm{P}$ ratios among experimental diets. Calcium intake exceeding the requirement has been suggested to lower intestinal absorption of $\mathrm{Ca}[24,25]$. As P concentrations in experimental diets were relatively constant in the present work, dietary Ca intake was dependent on $\mathrm{Ca}$ to $\mathrm{P}$ ratio in diets. Calcium to $\mathrm{P}$ ratio in the mixture diet was less than that in infertile egg diet and unhatched egg diet (1.8 vs 2.6 and 2.7 ). Compared with the daily Ca requirement suggested by NRC [20] for 11- to $25-\mathrm{kg}$ pigs $(6.3 \mathrm{~g} / \mathrm{d})$, dietary Ca intake of pigs fed to infertile egg diet and unhatched egg diet ( 8.1 and $7.8 \mathrm{~g} / \mathrm{d}$ ) exceeded the requirement whereas Ca intake of the mixture diet was $5.8 \mathrm{~g} / \mathrm{d}$ which was less than the requirement. The reason for greater measured digestible $\mathrm{Ca}$ in the mixture may be due to that the contribution of $\mathrm{Ca}$ supplied by infertile eggs and unhatched eggs in the mixture was over $80 \%$ and that the downregulation of intestinal Ca absorption of infertile eggs and unhatched eggs may have been alleviated in the mixture diet. However, Stein et al [21] reported that Ca digestibility was not compromised when the $\mathrm{Ca}$ to $\mathrm{P}$ ratio in the diet and daily $\mathrm{Ca}$ intake of $23-\mathrm{kg}$ pigs were up to 2.3 and $9.7 \mathrm{~g} / \mathrm{d}$ which are comparable to the values in the previous study [7]. The reason for the inconsistent results is unclear. Zhang and Adeola [14] reported that true total tract digestibility of $\mathrm{Ca}$ was additive in the $\mathrm{Ca}-\mathrm{P}$ balanced mixed diets containing limestone and dicalcium phosphate in 20-kg pigs. In their experiment [14], the amount of dietary $\mathrm{Ca}$ was below the daily Ca requirement ( 2.3 to $3.6 \mathrm{~g} / \mathrm{d}$ vs $6.3 \mathrm{~g} / \mathrm{d}$ ) and Ca to P ratios were relatively constant (0.9 to 1.0$)$.

No difference between measured and predicted AID and SID AA except for tryptophan in the mixture was observed. Each hatchery byproduct was the sole source of the respective experimental diet when determining AID and SID AA. The AID AA were not additive in the literature $[1,15]$. The major reason for the non-additivity was low AA concentrations in the ingredients. In the present work, however, each hatchery byproduct contains relatively high concentrations of AA, and thus, AID values in the mixture could have been relatively precisely predicted from each ingredient. Standardized ileal digestible AA are widely accepted to be additive in mixed diets $[6,15,23]$. The reason for non-additivity of SID tryptophan in the mixture remains unclear. The low tryptophan concentration in experimental diets possibly resulted in large errors in the measurement of tryptophan digestibility [6]. However, this speculation is not supported by the previous studies where tryptophan concentration was also the lowest among AA in experimental diets $[6,15,21]$.

\section{CONCLUSION}

Taken together, digestible energy and most AAs in hatchery byproducts were additive in the mixture fed to nursery pigs. However, digestible tryptophan, phosphorus, and calcium concentrations in the hatchery byproduct mixture deviated from the values calculated based on digestible nutrients in the ingredients.

\section{CONFLICT OF INTEREST}

We certify that there is no conflict of interest with any financial organization regarding the material discussed in the manuscript.

\section{FUNDING}

The authors are grateful for the support of Rural Development Administration (Republic of Korea; PJ01252803). The authors also would like to thank Join Inc. (Pyeongtaek, Republic of Korea) for providing the hatchery byproducts.

\section{REFERENCES}

1. Stein HH, Pedersen C, Wirt AR, Bohlke RA. Additivity of values for apparent and standardized ileal digestibility of amino acids in mixed diets fed to growing pigs. J Anim Sci 2005;83:2387-95. http://doi.org/10.2527/2005.83102387x

2. AAFCO. 2019 Official Publication. West Lafayette, IN, USA: Association of American Feed Control Officials; 2019.

3. Sung JY, Kim BG. Effects of a hatchery byproduct mixture on growth performance and digestible energy of various hatchery byproduct mixtures in nursery pigs. Animals 2020;10:174. http://doi.org/10.3390/ani10010174

4. Sung JY, Ji SY, Son AR, Kim BG. Energy concentration and phosphorus digestibility in hatchery byproducts fed to nursery pigs. Animals 2019;9:255. http://doi.org/10.3390/ani9050 255

5. Sung JY, Kim BG. Prediction equations for digestible and metabolizable energy concentrations in feed ingredients and diets for pigs based on chemical composition. Anim Biosci 2021;34:306-11. http://doi.org/10.5713/ajas.20.0293

6. Wang T, Osho SO, Adeola O. Additivity of apparent and standardized ileal digestibility of amino acid determined by chromic oxide and titanium dioxide in mixed diets containing wheat and multiple protein sources fed to growing pigs. J Anim Sci 2018;96:4731-42. http://doi.org/10.1093/jas/sky 326

7. Sung JY, Ji SY, Kim BG. Amino acid and calcium digestibility in hatchery byproducts fed to nursery pigs. Anim Feed Sci Technol 2020;270:114703. http://doi.org/10.1016/j.anifeedsci. 2020.114703 
8. Kong C, Adeola O. Evaluation of amino acid and energy utilization in feedstuff for swine and poultry diets. AsianAustralas J Anim Sci 2014;27:917-25. http://doi.org/10.5713/ ajas.2014.r.02

9. Seo S, Jeon S, Ha JK. - Editorial - Guidelines for experimental design and statistical analyses in animal studies submitted for publication in the Asian-Australasian Journal of Animal Sciences. Asian-Australas J Anim Sci 2018;31:1381-6. http:// doi.org/10.5713/ajas.18.0468

10. Karlsson CP, Lindberg JE, Rundgren M. Associative effects on total tract digestibility in horses fed different ratios of grass hay and whole oats. Livest Prod Sci 2000;65:143-53. http://doi.org/10.1016/S0301-6226(99)00178-5

11.Kim JW, Koo B, Nyachoti CM. Digestible, metabolizable, and net energy of camelina cake fed to growing pigs and additivity of energy in mixed diets. J Anim Sci 2017;95:403744. http://doi.org/10.2527/jas2017.1759

12.Lee SH, Jo H, Kim BG. Energy values of wheat bran are additive in corn-soybean meal-based swine diets. J Anim Sci 2017;95:192-3. http://doi.org/10.2527/asasann.2017.389

13. Fang RJ, Li TJ, Yin FG, et al. The additivity of true or apparent phosphorus digestibility values in some feed ingredients for growing pigs. Asian-Australas J Anim Sci 2007;20:1092-9. http://doi.org/10.5713/ajas.2007.1092

14.Zhang F, Adeola O. True is more additive than apparent total tract digestibility of calcium in limestone and dicalcium phosphate for twenty-kilogram pigs fed semipurified diets. J Anim Sci 2017;95:5466-73. http://doi.org/10.2527/jas2017. 1849

15.Xue PC, Ragland D, Adeola O. Determination of additivity of apparent and standardized ileal digestibility of amino acids in diets containing multiple protein sources fed to growing pigs. J Anim Sci 2014;92:3937-44. http://doi.org/10. 2527/jas.2014-7815

16. Son AR, Shin SY, Kim BG. Standardized total tract digestibility of phosphorus in copra expellers, palm kernel expellers, and cassava root fed to growing pigs. Asian-Australas J Anim
Sci 2013;26:1609-13. http://doi.org/10.5713/ajas.2013.13517

17.Son AR, Park CS, Park KR, Kim BG. Amino acid digestibility in plant protein sources fed to growing pigs. Asian-Australas J Anim Sci 2019;32:1745-52. http://doi.org/10.5713/ajas.19. 0037

18.Sung JY, Kim BG. Prediction models for apparent and standardized total tract digestible phosphorus in swine diets. Anim Feed Sci Technol 2019;255:114224. http://doi.org/ 10.1016/j.anifeedsci.2019.114224

19.Lee SA, Ahn JY, Son AR, Kim BG. Standardized ileal digestibility of amino acids in cereal grains and co-products in growing pigs. Asian-Australas J Anim Sci 2020;33:1148-55. http://doi.org/10.5713/ajas.19.0449

20.NRC. Nutrient requirements of swine, 11th ed.; Washington, DC, USA: National Academy Press; 2012.

21. Stein HH, Adeola O, Cromwell GL, et al. Concentration of dietary calcium supplied by calcium carbonate does not affect the apparent total tract digestibility of calcium, but decreases digestibility of phosphorus by growing pigs. J Anim Sci 2011;89:2139-44. http://doi.org/10.2527/jas.2010-3522

22.Zhai $\mathrm{H}$, Adeola O. True total-tract digestibility of phosphorus in corn and soybean meal for fifteen-kilogram pigs are additive in corn-soybean meal diet. J Anim Sci 2013;91:219-24. https:// doi.org/10.2527/jas.2012-5295

23. She Y, Wang Q, Stein HH, et al. Additivity of values for phosphorus digestibility in corn, soybean meal, and canola meal in diets fed to growing pigs. Asian-Australas J Anim Sci 2018; 31:1301-7. http://doi.org/10.5713/ajas.17.0547

24. Pansu D, Bellaton C, Bronner F. Effect of Ca intake on saturable and nonsaturable components of duodenal Ca transport. Am J Physiol 1981;240:G32-7. http://doi.org/10.1152/ajpgi. 1981.240.1.G32

25. Pointillart A, Fourdin A, Bourdeau A, Thomasset M. Phosphorus utilization and hormonal-control of calcium-metabolism in pigs fed phytic phosphorus diets containing normal or high calcium levels. Nutr Rep Int 1989;40:517-27. 